\title{
Photoperiodic Effects on Vegetative and Reproductive Growth of Vaccinium darrowi and V. corymbosum Interspecific Hybrids
}

Timothy M. Spann, Jeffrey G. Williamson, and Rebecca L. Darnell

Horticultural Sciences Department, University of Florida, Gainesville, FL 32611

Additional index words. daylength, flower bud initiation, flower development, southern highbush blueberry

Abstract. Experiments were conducted with $V$. darrowi and two cultivars of southern highbush blueberry, 'Sharpblue' and 'Misty,' to test whether $V$. darrowi and cultivars derived from it are photoperiodic with respect to flower bud initiation. Plants of each cultivar were grown under three different photoperiod treatments [long days $($ LD) $=$ 16-hour photoperiod; short days $(\mathrm{SD})=8$-hour photoperiod; and short days + night interrupt $(\mathrm{SD}-\mathrm{NI})=8$-hour photoperiod with 1-hour night interrupt] at constant $21^{\circ} \mathrm{C}$ for 8 weeks. Vegetative growth was greatest in the LD plants of both cultivars. Flower bud initiation occurred only in the SD treatments, and the lack of flower bud initiation in the SD-NI treatment indicates that flower bud initiation is a phytochrome mediated response in Vaccinium. Previously initiated flower buds on the V. darrowi plants developed and bloomed during the LD treatment, but bloom did not occur in the SD and SD-NI treatment plants until after those plants were moved to LD. These data indicate that flower bud initiation in both $V$. darrowi and southern highbush blueberry is photoperiodically sensitive, and is promoted by short days, while flower bud development is enhanced under long days.

Vaccinium darrowi Camp (Ocala form) has been used extensively in blueberry breeding programs for low chill climates (Lyrene, 1986). Because of its resistance to cane canker (Lyrene, 1986) and lack of a chilling requirement (Lyrene, 1997), V. darrowi is an important gene source for breeding the complex V. corymbosum L. interspecific hybrids known as southern highbush blueberry. Up to $31 \%$ of the genetic material in southern highbush blueberry cultivars comes from $V$. darrowi.

It is well documented that flower bud initiation in northern highbush (V. corymbosum L.), lowbush (V. angustifolium Ait.) and rabbiteye ( $V$. ashei Reade) blueberries is a quantitative short day response (Aalders and Hall, 1964; Darnell, 1991; Hall and Ludwig, 1961; Hall et al., 1970; Phatak and Austin, 1990); however, the role of photoperiod in flower bud initiation in southern highbush blueberry cultivars is unknown. Observations of southern highbush on the Corindi Plateau of New South Wales, Australia indicate that flower bud initiation occurs year round (Wright, 1993). Latitude and therefore photoperiod are very similar between the Corindi Plateau and north central Florida, but flower bud initiation does not occur year round in Florida. We tested the hypothesis that $V$. darrowi is not photoperiodic with respect to flower bud initiation and its use in breeding decreases the photoperiodic sensitivity of southern highbush blueberry compared with other cultivated Vaccinium species.

Received for publication 25 Mar. 2002. Accepted for publication 7 Nov. 2002. Florida Agricultural Experiment Station journal series R- 08917.

\section{Materials and Methods}

Expt. I. Vaccinium darrowi. In Apr. 1999, tip cuttings of $V$. darrowi (selection 91-313) were rooted in 50 peat : 50 perlite $(\mathrm{v}: \mathrm{v})$ with intermittent mist in a shaded greenhouse. After 6 weeks, rooted cuttings were transplanted into 2.5-L containers with pine bark medium and fertilized twice a month with $250 \mathrm{~mL}$ of $20 \mathrm{~N}$ 8.7P-16.6K water soluble fertilizer (ScottsSierra Horticultural Products Co., Marysville, Ohio) at $200 \mathrm{mg} \cdot \mathrm{L}^{-1} \mathrm{~N}$. Plants were grown in a greenhouse under natural daylength and average $21^{\circ} \mathrm{C}$ day $/ 18{ }^{\circ} \mathrm{C}$ night temperatures. On 14 Feb. 2000, 30 plants were selected for uniformity and blocked into 10 replications of 3 plants each according to total cane length (block averages ranged from 35 to $79 \mathrm{~cm}$ ). At this time, lateral shoots were pruned below the lowest distinguishable flower bud.

On 1 Mar. 2000, one plant from each replication was randomly assigned to one of the following treatments: long days $(\mathrm{LD})=16-\mathrm{h}$ photoperiod; short days (SD) $=8$-h photoperiod; and short days + night interrupt (SD-NI) $=8$ - $\mathrm{h}$ photoperiod with 1 - $\mathrm{h}$ night interrupt in the middle of the dark cycle. The design was a randomized complete block with 10 single plant replications. Plants in each treatment were placed in growth chambers (Conviron model E15, Controlled Environments, Winnipeg, Manitoba, Canada) set to maintain a constant day/night temperature of $21^{\circ} \mathrm{C}$. Photosynthetic photon flux $(P P F)$ averaged $390 \mu \mathrm{mol} \cdot \mathrm{m}^{-2} \cdot \mathrm{s}^{-1}$ with a 4 red : 1 far red ratio during the day and $150 \mu \mathrm{mol} \cdot \mathrm{m}^{-2} \cdot \mathrm{s}^{-1}$ with a 3 red : 1 far red ratio during the night interrupt. Plants were checked daily and irrigated as needed. Fertilizer was withheld for the duration of the treatments.

On 26 Apr. 2000, plants were removed from the photoperiod treatments and placed in a modified walk-in cooler with incandescent and high-output flourescent lights. All plants were grown for 8 weeks under LD (16-h photoperiod), $P P F$ of $300 \mu \mathrm{mol} \cdot \mathrm{m}^{-2} \cdot \mathrm{s}^{-1}$ and a red : far red ratio of 3.3:1. Temperature was constant at $21^{\circ} \mathrm{C}$. Fertilization was resumed on a weekly basis at the rate previously described.

Terminal bud formation, if it occurred, was recorded as number of days from the beginning of photoperiod treatments. Total cane length (including all lateral canes) was recorded at the beginning of the experiment and every 2 weeks for 6 weeks after the photoperiod treatments ended. Shoot length measurements were not taken during the photoperiod treatments. Total number of flower buds per plant was recorded weekly for 8 weeks after the end of the photoperiod treatments. Flower buds were recorded as either being on old growth (defined as growth present at the start of the photoperiod treatments) or new growth (defined as growth produced during the photoperiod treatments), to distinguish buds initiated during the treatments from those that were initiated before the treatments were applied. Flower buds were removed when individual flowers were distinctly separated but before corollas were fully expanded (development stage 5, Spiers, 1978).

Expt. II. Vaccinium corymbosum interspecific hybrids. On 4 Apr. 2000, 32 1-year-old plants each of two southern highbush blueberry cultivars, 'Sharpblue' and 'Misty', were obtained from a commercial blueberry farm. These cultivars were chosen based on their difference in flower bud initiation. 'Sharpblue' initiates a moderate number of flower buds relative to vegetative buds, whereas 'Misty' is a heavy flowering cultivar (Maust et al., 1999). Plants were repotted into 5-L containers using pine bark medium. Dead stems and fine, twiggy growth were removed from both cultivars at repotting. The plants were fertilized weekly with $500 \mathrm{~mL}$ of $20 \mathrm{~N}-8.7 \mathrm{P}-16.6 \mathrm{~K}$ water soluble fertilizer (Scotts-Sierra Horticultural Products Co.) at $200 \mathrm{mg} \cdot \mathrm{L}^{-1} \mathrm{~N}$. Plants were acclimated in a greenhouse for 5 weeks prior to treatment, with temperatures averaging 21 ${ }^{\circ} \mathrm{C}$ day $/ 18^{\circ} \mathrm{C}$ night, $700 \mu \mathrm{mol} \cdot \mathrm{m}^{-2} \cdot \mathrm{s}^{-1} \mathrm{PPF}$ and an average photoperiod of $12 \mathrm{~h}$ and $50 \mathrm{~min}$. During this time, daylength was extended to $16 \mathrm{~h}$ by supplemental lighting using $100 \mathrm{~W}$ incandescent lights (spaced $\approx 1.2 \mathrm{~m} \times 0.6 \mathrm{~m}$ apart and $0.3 \mathrm{~m}$ above the plants) providing 50 $\mu \mathrm{mol} \cdot \mathrm{m}^{-2} \cdot \mathrm{s}^{-1} P P F$ at the plant canopy.

On 10 May 2000, plants of both cultivars were selected for uniformity and blocked into 10 replications of 3 plants each according to total cane length. One plant of each cultivar from each replication was randomly assigned to LD, SD, or SD-NI treatments, as previously described. The design was a randomized complete block with 10 single plant replications. Plants in each treatment were placed in growth chambers (Conviron model E15) at the appropriate photoperiod, and a constant day/night temperature of $21^{\circ} \mathrm{C} . P P F$ averaged 
$480 \mu \mathrm{mol} \cdot \mathrm{m}^{-2} \cdot \mathrm{s}^{-1}$ with a 4 red $: 1$ far red ratio during the day and $145 \mu \mathrm{mol} \cdot \mathrm{m}^{-2} \cdot \mathrm{s}^{-1}$ with a 3 red : 1 far red ratio during the night interrupt. Plants were checked daily and irrigated as needed. Fertilizer was withheld for the duration of the treatments.

On 5 July 2000, all plants were removed from the photoperiod treatments and placed in a modified walk-in cooler with incandescent and high-output flourescent lights. Plants were grown for 8 weeks under LD, $P P F$ of $300 \mu \mathrm{mol} \cdot \mathrm{m}^{-2} \cdot \mathrm{s}^{-1}$ and a 3.3 red : 1 far red ratio. Temperatures were constant at $21{ }^{\circ} \mathrm{C}$. Fertilization was resumed on a weekly basis at the rate previously described.

Total cane length was recorded as described for Expt. I, but was carried out through week 8 of the post-treatment period. Flower buds were counted and removed as described for Expt. I except that buds were not separated as being from old and new growth since no flower buds were present at the start of the experiment. Net $\mathrm{CO}_{2}$ assimilation was measured twice during the photoperiod treatments, during the light cycles and the night interrupt period, and once during the 8-week observation period, using a Parkinson leaf chamber attached to a portable leaf chamber analyzer and air supply unit (Analytical Development Co., Hoddesdon, England). Net $\mathrm{CO}_{2}$ assimilation data were collected from recently expanded, mature leaves at least $1 \mathrm{~h}$ after the beginning of the light period (45 min for the night interrupt) to ensure photosynthesis had equilibrated for the given conditions.

Data were analyzed by analysis of variance (SAS, PROC GLM) and mean separation was determined by Duncan's multiple range test $(P=0.05)$ (SAS Institute, Cary, N.C.).

\section{Results}

Expt. I. Vaccinium darrowi. Total cane length was similar for all plants prior to placing them in the photoperiod treatments, averaging $60 \mathrm{~cm}$. At the end of the photoperiod treatments, cane length of plants under LD was significantly greater compared with SD or SD-NI plants (Fig. 1). Growth rate (expressed as percent increase in total cane length between measurements) was greatest for the LD plants during the photoperiod treatments (data not shown). However, after being placed in post-treatment LD conditions, all plants, regardless of photoperiod treatment, exhibited similar growth rates. Terminal bud formation occurred during the fifth week of the photoperiod treatment in the SD plants, but did not occur in the SD-NI or LD plants.

Photoperiod did not affect flower bud number on old canes of $V$. darrowi (Table 1 ). However, plants grown under SD produced more flower buds on new canes compared with plants grown under LD or SD-NI. Bloom occurred prior to the end of the photoperiod treatment for the LD plants (Fig. 2) but did not occur in the SD-NI and SD treatments until 3 to 4 weeks and 4 to 5 weeks of the post-treatment period, respectively. All treatments reached $100 \%$ bloom by week 7 of the post-treatment period (Fig. 2).

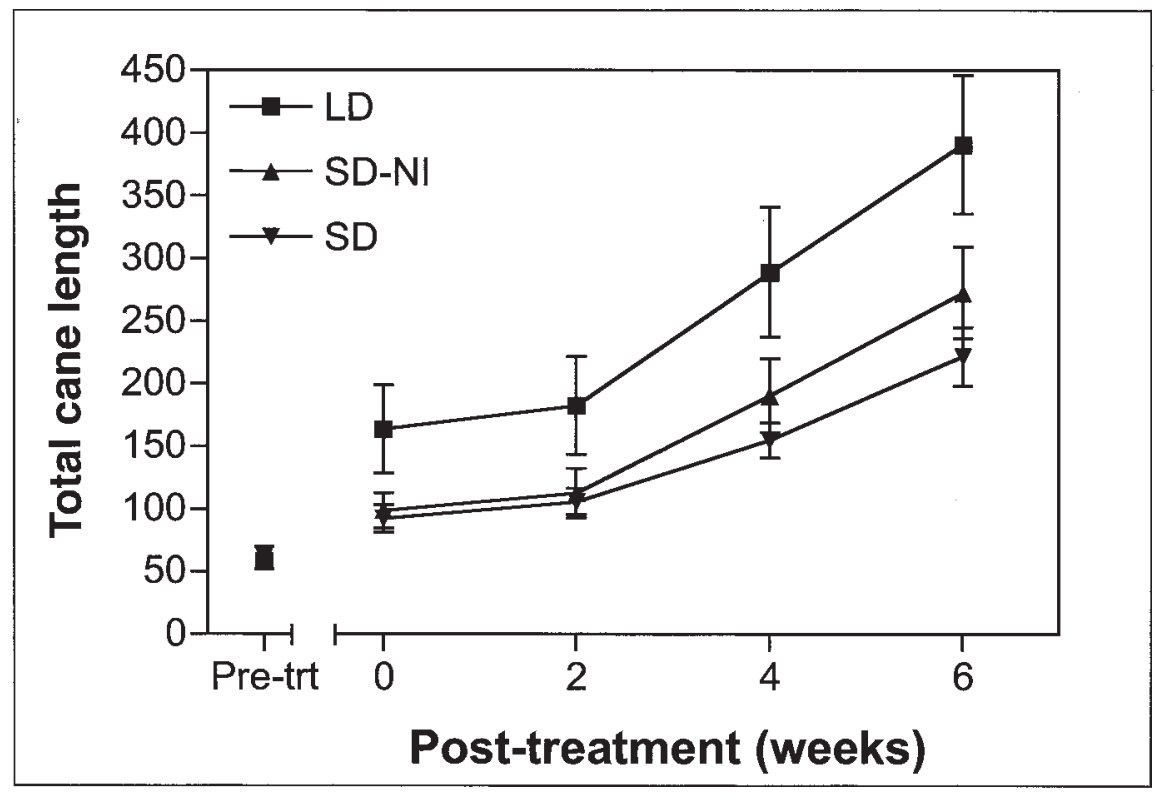

Fig. 1. Total cane length of Vaccinium darrowi under long day $(\mathrm{LD}=16 \mathrm{~h}$ photoperiod), short day + night interrupt (SD-NI $=8 \mathrm{~h}$ photoperiod $+1 \mathrm{~h}$ night interrupt) and short day ( $\mathrm{SD}=8 \mathrm{~h}$ photoperiod) photoperiod treatments (means $\pm \mathrm{SE}, \mathrm{n}=10$ ).
Expt. II. V. corymbosum interspecific hybrids. Total cane length was similar for all plants of each cultivar prior to placing them in the photoperiod treatments, averaging $260 \mathrm{~cm}$ and $200 \mathrm{~cm}$ for 'Sharpblue' and 'Misty', respectively. At the end of the photoperiod treatments, cane length was greater in plants under LD compared with SD-NI or SD plants, and plants under SD-NI had greater cane length than SD plants for both cultivars (Fig. 3). Growth rate (expressed as percent increase in total cane length between measurements) was greatest for the LD plants during the photoperiod treatments for both cultivars, but plants grew at similar rates during the post-treatment period regardless of previ- ous photoperiod treatment (data not shown). Terminal bud formation occurred between 5 and 6 weeks of the SD photoperiod treatment in 'Sharpblue' and 'Misty,' but did not occur in the SD-NI or LD treatments.

In both cultivars, plants grown under SD initiated more flower buds compared with plants under LD or SD-NI treatments (Table 2). 'Misty' produced about $32 \%$ more flower buds than 'Sharpblue,' typifying the heavy flowering characteristic of this cultivar. Fifty percent bloom did not occur in 'Sharpblue' during the post-treatment observation period, and occurred at week 7 for 'Misty' (Fig. 4).

$\mathrm{Net} \mathrm{CO}_{2}$ assimilation was greater in leaves under SD and SD-NI conditions in both cul-

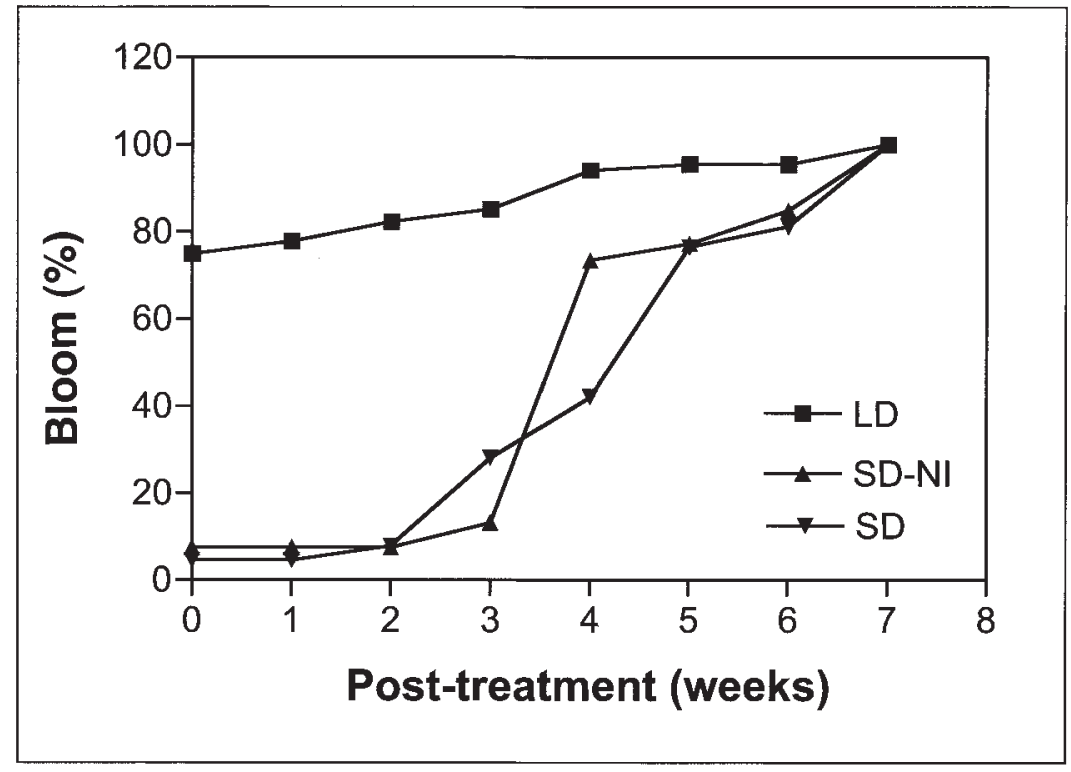

Fig. 2. Cumulative percent bloom for $V$. darrowi under long days ( $\mathrm{LD}=16 \mathrm{~h}$ photoperiod), short days + night interrupt (SD-NI $=8 \mathrm{~h}$ photoperiod $+1 \mathrm{~h}$ night interrupt $)$ and short days $(\mathrm{SD}=8 \mathrm{~h}$ photoperiod) photoperiod treatments $(\mathrm{n}=10)$. 
Table 1. Flower bud number in $V$. darrowi after 8 weeks of photoperiod treatments.

\begin{tabular}{lcc}
\hline & \multicolumn{2}{c}{ Avg flower buds per plant } \\
\cline { 2 - 3 } Treatment & Old canes & New canes \\
\hline LD $^{\mathrm{z}}$ & $6.8 \mathrm{a}^{\mathrm{y}}$ & $0.0 \mathrm{~b}$ \\
SD-NI & $5.3 \mathrm{a}$ & $0.2 \mathrm{~b}$ \\
SD & $8.9 \mathrm{a}$ & $10.4 \mathrm{a}$ \\
\hline
\end{tabular}

${ }^{2} \mathrm{LD}=$ long day, $16 \mathrm{~h}$ photoperiod; SD-NI = short day night interrupt, $8 \mathrm{~h}$ photoperiod $+1 \mathrm{~h}$ night interrupt; $\mathrm{SD}=$ short day, $8 \mathrm{~h}$ photoperiod.

'Lowercase letters indicate mean separation within columns by Duncan's multiple range test, $P \leq 0.05, \mathrm{n}=10$

tivars $\left(12.0 \pm 0.3 \mu \mathrm{mol} \cdot \mathrm{m}^{2} \cdot \mathrm{s}^{-1}\right.$ of $\left.\mathrm{CO}_{2}\right) \mathrm{com}-$ pared with those under LD conditions $(8.3 \pm$ $1.1 \mu \mathrm{mol} \cdot \mathrm{m}^{2} \cdot \mathrm{s}^{-1}$ of $\left.\mathrm{CO}_{2}\right)$. Net $\mathrm{CO}_{2}$ assimilation during the 1-h night interrupt was minimal (2.1 $\pm 0.5 \mu \mathrm{mol} \cdot \mathrm{m}^{2} \cdot \mathrm{s}^{-1}$ of $\mathrm{CO}_{2}$ )

\section{Discussion}

Vegetative and reproductive development in both V. darrowi and V. corymbosum hybrids
Table 2. Flower bud number in 'Sharpblue' and 'Misty' southern highbush blueberry after 8 weeks of photoperiod treatments.

\begin{tabular}{lcr}
\hline & \multicolumn{2}{c}{ Avg flower buds per plant } \\
\cline { 2 - 3 } Treatment & Sharpblue & Misty \\
\hline $\mathrm{LD}^{\mathrm{z}}$ & $0.0 \mathrm{~b}^{\mathrm{y}}$ & $0.0 \mathrm{~b}$ \\
SD-NI & $0.5 \mathrm{~b}$ & $0.5 \mathrm{~b}$ \\
$\mathrm{SD}$ & $60.7 \mathrm{a}$ & $80.5 \mathrm{a}$ \\
\hline${ }^{2} \mathrm{LD}=$ long day, $16 \mathrm{~h}$ photoperiod; & SD-NI \\
$=$ short day night interrupt, 8 h photoperiod \\
$+1 \mathrm{~h}$ night interrupt; SD = short day, $8 \mathrm{~h}$ \\
photoperiod. \\
'Lowercase letters indicate mean separation \\
within columns by Duncan's multiple range \\
test, $P \leq 0.05, \mathrm{n}=10$.
\end{tabular}

was profoundly influenced by photoperiod. Increasing vegetative growth is positively correlated with increasing photoperiod in several species (Downs and Borthwick, 1956), including northern highbush (Hall et al., 1963) and lowbush blueberry (Hall and Ludwig, 1961). In the present study, the decrease in cane growth in the SD and SD-NI treatments compared with the LD treatments for both species suggests the photoperiod effect on vegetative growth

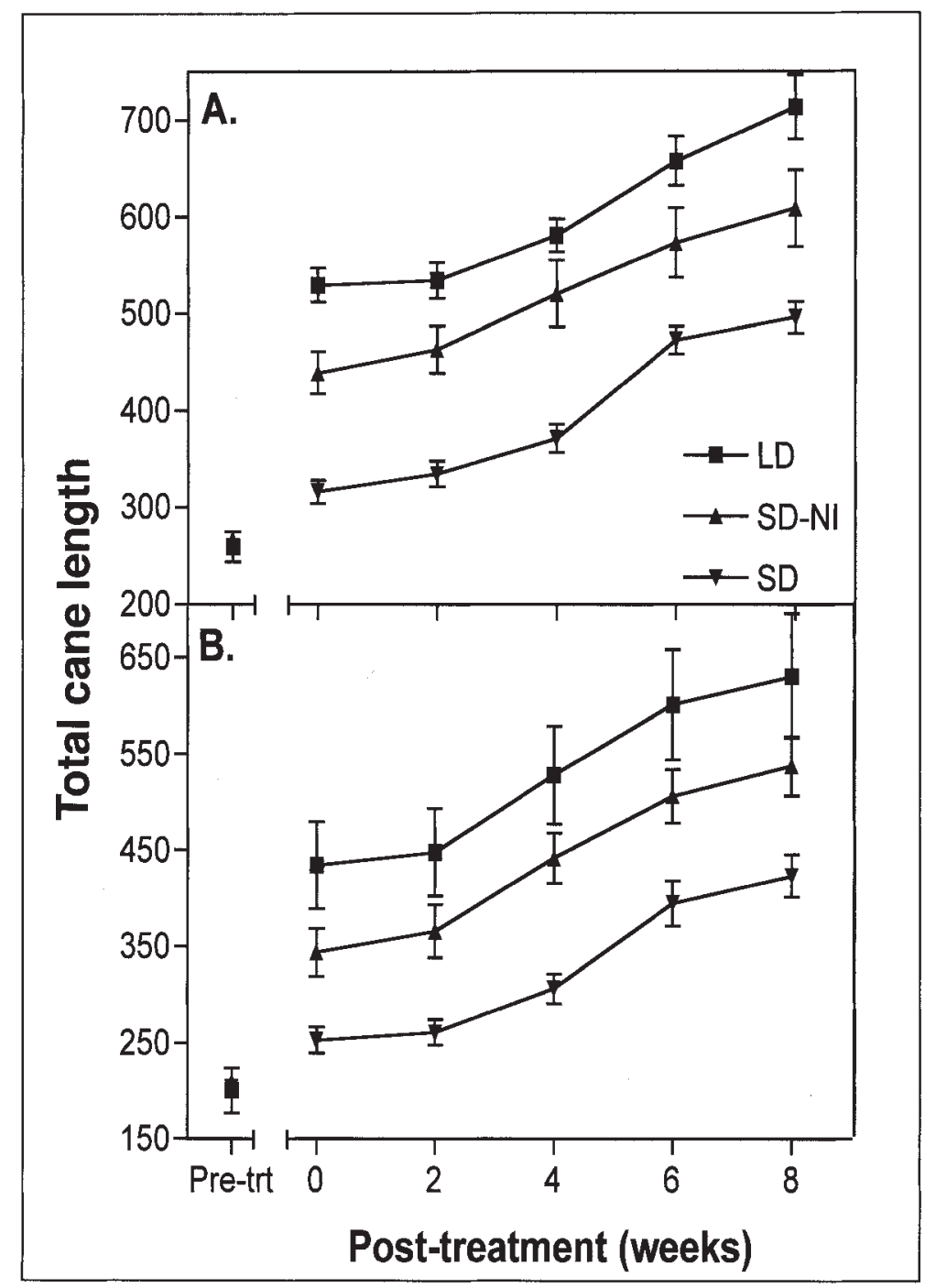

Fig. 3. Total cane length of 'Sharpblue' (A) and 'Misty' (B) southern highbush blueberry under long day $(\mathrm{LD}=16 \mathrm{~h}$ photoperiod), short day + night interrupt $(\mathrm{SD}-\mathrm{NI}=8 \mathrm{~h}$ photoperiod $+1 \mathrm{~h}$ night interrupt $)$ and short day ( $\mathrm{SD}=8 \mathrm{~h}$ photoperiod) photoperiod treatments (means $\pm \mathrm{SE}, \mathrm{n}=10$ ).

in Vaccinium is not phytochrome-mediated. If phytochrome were involved, it would be expected that a night interrupt treatment would have a similar effect on cane growth as the LD treatment. It is more likely that the effect of increasing photoperiod on increasing vegetative growth is a carbohydrate effect. Although leaf net assimilation rates for 'Sharpblue' and 'Misty' were greater in the SD and SD-NI treatments than in the LD treatment, as reported in rabbiteye blueberry underLD vs. SD conditions (Darnell, 1991), the longer photoperiod in the LD treatments may have resulted in increased daily net $\mathrm{CO}_{2}$ assimilation. Assuming the differences in $\mathrm{CO}_{2}$ assimilation among photoperiod treatments were maintained throughout the light period, daily $\mathrm{CO}_{2}$ assimilation in $\mathrm{LD}$ plants would have been greater $(\approx 478 \mathrm{mmol}$ $\mathrm{CO}_{2} / \mathrm{m}^{2}$ per day) than in SD or SD-NI plants $\left(\approx 346 \mathrm{mmol} \mathrm{CO} / \mathrm{m}^{2}\right.$ per day) due to the $8 \mathrm{~h}$ of additional light received by the LD plants Thus, even though net assimilation rate was lower in LD plants, total photosynthates may have been higher, resulting in increased growth.

The increase in flower buds on new canes under SD conditions in both species is similar to that reported for lowbush (Hall and Ludwig, 1961), highbush (Hall et al., 1963), and rabbiteye (Darnell, 1991; Phatak and Austin, 1990) blueberries. Hall and Ludwig (1961) were the first to show that flower bud initiation in lowbush blueberry is a SD photoperiodic response. In highbush blueberry, photoperiods of 14 or $16 \mathrm{~h}$ inhibit flower bud initiation compared with 8-, 10-, or 12-h photoperiods (Hall et al., 1963). In general, 5 to 6 weeks of inductive short days are required for normal flower bud initiation in blueberry (Darnell, 1991; Hall et al., 1963; Phatak and Austin, 1990).

Although many studies have demonstrated the effect of LD vs. SD on flower bud initiation in Vaccinium, the use of a night interrupt to verify the involvement of phytochrome in this response has not been examined. In the present study, the inhibition of flower bud initiation in the SD-NI treatment indicates that flower bud initiation in Vaccinium is a phytochrome- mediated response. The night interrupt treatment mimics the effect of a long-day treatment, in part by preventing phytochrome far-red levels from decreasing below some critical level necessary for a response (Vince-Prue, 1986). The lack of a significant difference in flower bud number on old canes in V.darrowi suggests that these flower buds were initiated under natural short days in the greenhouse prior to the start of the experiment.

There is little information in the current literature on photoperiod effects on the rate of development of initiated flower buds in blueberry. Previously initiated flower buds on plants of $V$. darrowi in the LD treatment developed faster than those in either the SDNI or SD treatments. This is similar to what has been shown for many plants, including strawberry (Fragaria $\times$ ananassa) (Durner and Poling, 1987; Guttridge, 1969) and Cestrum nocturnum L. (Sachs, 1969). Flower bud initiation and flower bud development are distinct processes, both of which are influenced by photoperiod in Vaccinium; short photoperi- 


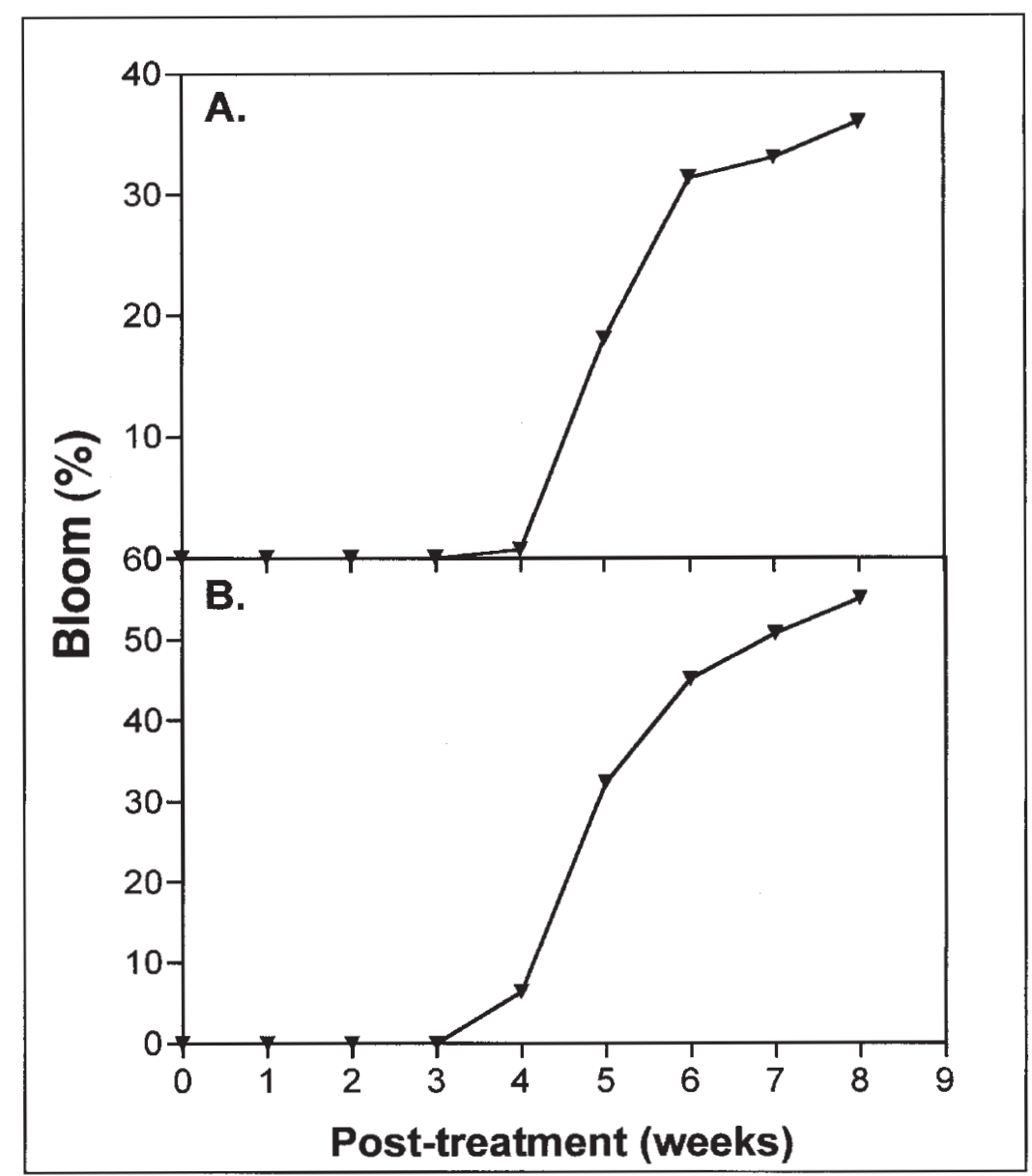

Fig. 4. Cumulative percent bloom for 'Sharpblue'(A) and 'Misty' (B) southern highbush blueberries under short day $(8 \mathrm{~h})$ photoperiods $(\mathrm{n}=10)$.

ods increase flower bud initiation, while long photoperiods increase the rate of flower bud development.

The results of the present experiment indicate that flower bud initiation in both $V$. darrowi and $V$. corymbosum interspecific hybrids was photoperiodically sensitive at moderate temperatures, as is the case with other cultivated Vaccinium species. It is not known why southern highbush cultivars initiate flower buds under a wider range of photoperiods in Australia (Wright, 1993) than Florida, but average temperatures in the blueberry growing areas in Australia are $4{ }^{\circ} \mathrm{C}$ lower than in Florida, and temperature may play an important role in the initiation response, as it does in many photoperiodically sensitive plants (Bernier, et al., 1981; Pettersen, 1972; Sonsteby, 1997). In strawberry, for example, the short day requirement for flower initiation can be overridden by low temperatures, and initiation in some short day cultivars can occur at photoperiods of 16 to $24 \mathrm{~h}$ at temperatures below $15^{\circ} \mathrm{C}$ (Heide, 1977). Conversely, high
116:856-860.

Downs, R.J. and HA. Borthwick. 1956. Effects of photoperiod on growth of trees. Bot. Gaz. 117:310-326.

Durner, E.F., J.A. Barden, D.G. Himelrick, and E.B. Poling. 1984. Photoperiod and temperature effects on flower and runner development in day-neutral, junebearing, and everbearing strawberries. J. Amer. Soc. Hort. Sci. 109: 396-400.

Durner, E.F. and E.B. Poling. 1987. Flower bud induction, initiation, differentiation and development in the 'Earliglow' strawberry. Sci. Hort. 31:61-69.

Guttridge, C.G. 1969. Fragaria. In: L.T. Evans (ed.). The induction of flowering. Cornell Univ. Press, Ithaca, N.Y.

Hall, I.V., D.L. Craig. and L.E. Aalders. 1963. The effect of photoperiod on the growth and flowering of the highbush blueberry (Vaccinium corymbosum L.). Proc. Amer. Soc. Hort. Sci. 82:260-263.

Hall, I.V., F.R. Forsyth. and R.J. Newbery. 1970. Effect of temperature on flower bud and leaf anthocyanin formation in the lowbush blueberry. HortScience 5:272-273.

Hall, I.V. and R.A. Ludwig. 1961. The effects of photoperiod, temperature, and light intensity on the growth of the lowbush blueberry (Vaccinium angustifolium Ait.). Can. J. Bot. 39: 1733-1739.

Heide, O. 1977. Photoperiod and temperature interactions in growth and flowering of strawberry. Physiol. Plant. 40:21-26.

Lyrene, P.M. 1986. Variation within Vaccinium darrowi blueberry in Florida. HortScience 21: 512-514.

Lyrene, P.M. 1997. Value of various taxa in breeding tetraploid blueberries in Florida. Euphytica 94:15-22.

Maust, B.E., J.G. Williamson, and R.L. Darnell. 1999. Flower bud density affects vegetative and fruit development in field-grown southern highbush blueberry. HortScience 34:607-610.

Pettersen, H. 1972. The effect of temperature and daylength on shoot growth and bud formation in azaleas. J. Amer. Soc. Hort. Sci. 97:17-23.

Phatak, S.C. and M.E. Austin. 1990. The effect of photoperiod on the growth and flowering of two rabbiteye blueberry cultivars. Appl. Agr. Res. 5:350-352.

Sachs, R.M. 1969. Cestrum nocturnum L. In: L.T Evans (ed.). The induction of flowering. Cornell Univ. Press, Ithaca, N.Y.

Sonsteby, A. 1997. Short-day period and temperature interactions on growth and flowering of strawberry. Acta Hort. 439:609-616.

Spann, T.M. 2001. Environmental influences on flower bud initiation in Vaccinium species. MS thesis, Univ. Florida, Gainesville.

Spiers, J.M. 1978. Effect of stage of bud development on cold injury in rabbiteye blueberry. $\mathrm{J}$. Amer. Soc. Hort. Sci. 103:452-455.

Vince-Prue, D. 1986. The duration of light and photoperiodic responses, p. 269-305. In: R.E. Kendrick and G.H.M. Kronenberg (eds.). Photomorphogenesis in plants. Martinus Nijhoff/Dr. W. Junk Publishers, Dordrecht.

Wright, G. 1993. Performance of southern highbush and rabbiteye blueberries on the Corindi Plateau N.S.W. Australia. Acta Hort. 346:141-148. 